\title{
Estimated carbon dioxide exchange for three native species in an ecological reserve of Mexico City
}

\author{
ERIKA SÁNCHEZ-LEÓN, TELMA CASTRO, ÓSCAR PERALTA, HARRY ÁLVAREZ-OSPINA, \\ MARÍA DE LA LUZ ESPINOSA and AMPARO MARTÍNEZ-ARROYO \\ Centro de Ciencias de la Atmósfera, Universidad Nacional Autónoma de México, Circuito de la Investigación \\ Cientifica s/ $n$, Ciudad Universitaria, 04510 Ciudad de México, México \\ Corresponding author: Erika Sánchez-León; email: erikas@atmosfera.unam.mx
}

Received: December 10, 2015; accepted: May 11, 2016

\begin{abstract}
RESUMEN
Se estimó la captura y emisión de $\mathrm{CO}_{2}$ de tres especies (Buddleia cordata, Senecio praecox y Echeveria gibbiflora) en la Reserva Ecológica del Pedregal de San Ángel. El muestreo se realizó durante los meses de febrero, marzo, abril y noviembre (temporada seca) y de julio a octubre (temporada de lluvias) en 2010. En la temporada seca $B$. cordata y $S$. praecox capturaron 16.14 y $3.25 \mathrm{~kg}$ de $\mathrm{CO}_{2}$, respectivamente, en tanto que E. gibbiflora emitió $45.76 \mathrm{~kg}$ de $\mathrm{CO}_{2}$. En la temporada de lluvias el intercambio de $\mathrm{CO}_{2}$ fue diferente para las tres especies. La tasa de fotosíntesis durante la temporada seca y de lluvias fue respectivamente de 22 y $6 \mu \mathrm{mol} \mathrm{CO} \mathrm{m}^{-2} \mathrm{~s}^{-1}$ para $B$. cordata, 27 y $5.25 \mu \mathrm{mol} \mathrm{CO} \mathrm{CO}^{-2} \mathrm{~s}^{-1}$ para $S$. praecox, y 29 y $3 \mu \mathrm{mol} \mathrm{CO} \mathrm{C}^{-2} \mathrm{~s}^{-1}$ para E. gibbiflora. Adicionalmente, se estimó el índice de vegetación de diferencia normalizada con datos de MODIS. Los resultados indican que la intensidad del verdor en el sitio aumentó durante los meses de lluvia. En este trabajo se explica la contribución de dichas plantas al ciclo de carbono en un ecosistema ubicado dentro de una zona urbana, así como la relación de variables ambientales como temperatura, densidad del flujo fotosintético de fotones y humedad relativa en la captura o emisión de $\mathrm{CO}_{2}$. Este trabajo proporciona información sobre la dinámica del ciclo del carbono en ecosistemas urbanos, lo cual puede ser útil para estudios futuros sobre la mitigación del cambio climático.
\end{abstract}

\begin{abstract}
Capture and emission of carbon dioxide of three species (Buddleia cordata, Senecio praecox and Echeveria gibbiflora) in the Reserva Ecológica del Pedregal de San Ángel (Ecological Reserve of the Pedregal de San Ángel), were estimated. $\mathrm{CO}_{2}$ sampling was carried out in 2010 during the dry (February, March, April and November) and rainy seasons (July to October). On the dry season B. cordata and S. praecox captured 16.14 and $3.25 \mathrm{~kg} \mathrm{CO}_{2}$, respectively, whereas E. gibbiflora emitted $45.76 \mathrm{~kg} \mathrm{CO}_{2}$. In the rainy season the exchange of $\mathrm{CO}_{2}$ was different for the three species. In the dry season, the photosynthetic rate was $22 \mu \mathrm{mol} \mathrm{CO} \mathrm{Cm}^{-2} \mathrm{~s}^{-1}$ for B. cordata, $27 \mu \mathrm{molCO}_{2} \mathrm{~m}^{-2} \mathrm{~s}^{-1}$ for $S$. praecox and $29 \mu \mathrm{molCO}_{2} \mathrm{~m}^{-2} \mathrm{~s}^{-1}$ for E. gibbiflora. In the rainy season they were $6,5.25$ and $3 \mu \mathrm{mol} \mathrm{CO}_{2} \mathrm{~m}^{-2} \mathrm{~s}^{-1}$, respectively. In addition, MODIS data were used to estimate the normalized difference vegetation index (NDVI), indicating that the intensity of greenery at the site increased during the rainy months. This paper explains the contribution of studied plants to the carbon cycle of an ecosystem located within an urban area, and the relationship of environmental variables such as temperature, density photosynthetic photon flux and relative humidity in the capture or emission of $\mathrm{CO}_{2}$. This work provides valuable information about the carbon cycle dynamics on urban ecosystems, which can be useful in future studies for climate change mitigation.
\end{abstract}

Keywords: Photosynthesis, Buddleia cordata, Senecio praecox, Echeveria gibbiflora, capture and emission $\mathrm{CO}_{2}$, Mexico City. 


\section{Introduction}

The global warming phenomenon, which is caused by emissions of greenhouse gases (GHGs) that contribute to an increase in earth surface temperature, is presented nowadays as a problem for the development of life on earth. Carbon dioxide $\left(\mathrm{CO}_{2}\right)$ is one of the gases that most favors the heating process, and its concentration has increased in recent years mainly due to anthropogenic activities, going from $280 \mathrm{ppm}$ in pre-industrial times to $398.72 \mathrm{ppm}$ in 2014 (IPCC, 2007; NOAA, 2014). According to the national inventory of GHGs of Mexico, the total $\mathrm{CO}_{2}$ emissions were $493.45 \mathrm{Mt}$ in 2010, contributing with $65.9 \%$ to the total inventory and having an increase of $23.6 \%$ compared to 1990 (INE, 2010).

There are various carbon sinks in the world that have been associated to an important contribution of forests, which are responsible for $60 \%$ of the net sequestration of carbon dioxide (Nobel, 2009). It is estimated that the world's forests capture over $650 \mathrm{Mt}$ of carbon, which helps to mitigate climate change and preserve biodiversity (FAO, 2010). However, not only forests sequestrate $\mathrm{CO}_{2}$; it has been shown in several studies that the presence of trees in urban areas favors the reduction of some air pollutants and contributes to carbon sequestration (Yang et al., 2005; Kordowski and Kuttler, 2010; Velasco et al., 2013). There are several techniques for estimating carbon sequestration; one of them is through the use of technologies such as satellite imagery from the Moderate Resolution Imaging Spectroradiometer (MODIS), whose purpose is to model carbon and water cycles globally. Furthermore, MODIS allows measuring ecosystem's primary productivity, vegetation indices and other environmental variables (Zhao et al., 2005).

The captured carbon is also estimated using different models, which evaluate photosynthetic and environmental parameters (Kim and Lieth, 2003; Schultz 2003; Xu and Baldocchi, 2003; Sharkey et al., 2007), whereas others evaluate the carbon balance between plants and the atmosphere (Harnos et al., 2006). Several experimental studies of photosynthesis use $\mathrm{CO}_{2}$ analyzers and measurements in situ (Myers et al., 1999; Long and Bernacchi, 2003; Kitao et al., 2007). However, few studies have evaluated the importance of individual species concerning their contribution to $\mathrm{CO}_{2}$ capture and emission in the environment. This information provides knowledge over the role of vegetation. Urban forests can contribute significantly to the reduction of air pollution by relieving the intensity of the heat island (Yang et al., 2005). Velasco et al. (2013) mentioned that vegetation in an urban area contributes to the capture of $\mathrm{CO}_{2}$ during the day and promotes local air cooling due to transpiration, serving as an alternative mitigation for climate change.

In this study our objective was to estimate $\mathrm{CO}_{2}$ capture and emission through the photosynthetic rate of three endemic plants (E. gibbiflora, $B$. cordata, and $S$. praecox) and the relationship between temperature $(\mathrm{T})$, density photosynthetic photon flux (DPPF), and relative humidity (RH) in dry and rainy seasons at the Reserva Ecológica del Pedregal de San Ángel (Ecological Reserve of the Pedregal de San Ángel, REPSA); we also estimated the contribution to the carbon cycle to understand the role of urban plant ecosystems in climate change mitigation. This site was chosen because it is one of the few protected natural reserves located in a megacity; moreover, it is of great value for the conservation of biodiversity and it provides environmental services to the south of the metropolitan area of Mexico City. It also has a special ecosystem, a xerophilus shrubland settled into a basaltic substrate whose soils are scarce and shallow (Rzedowski, 1954), which is the reason why this work is focused on the aboveground biomass. The carbon cycle in vegetation starts with $\mathrm{CO}_{2}$ fixation mainly in the photosynthetic processes in which the plants absorb $\mathrm{CO}_{2}$ from the atmosphere to produce oxygen and carbohydrates through solar radiation. We hypothesized that different climatic conditions produce significant changes regarding the carbon balance during the dry and rainy seasons.

\section{Experimental}

\subsection{Sampling site description}

This study was conducted in the REPSA, located southeast of Mexico City (19 $17^{\circ}$ N, $\left.99^{\circ} 11^{\prime} \mathrm{W}\right)$. It covers an area of approximately 273 hectares and its nominal elevation is 2329 masl. The vegetation consists of xerophilous shrubs and dominant life forms are herbs and shrubs (Castillo-Argüero et al., 2007; Chávez and Ceballos, 2009). According to Jáuregui (2000) the climate has dry and rainy seasons. The dry season runs from November to May and the rainy 
season from June to October. The average annual precipitation is $803 \mathrm{~mm}$ and mean annual temperature is $15.6{ }^{\circ} \mathrm{C}$.

Figure 1 shows monthly average temperature and precipitation for 2010, obtained from a weather station near the sampling point. The highest temperature during that year was recorded in May with an average value of $20^{\circ} \mathrm{C}$, and the lowest was $12{ }^{\circ} \mathrm{C}$ in December. The highest precipitation was $255 \mathrm{~mm}$ in July and the lowest values were 3 and $0 \mathrm{~mm}$ in November and December, respectively.

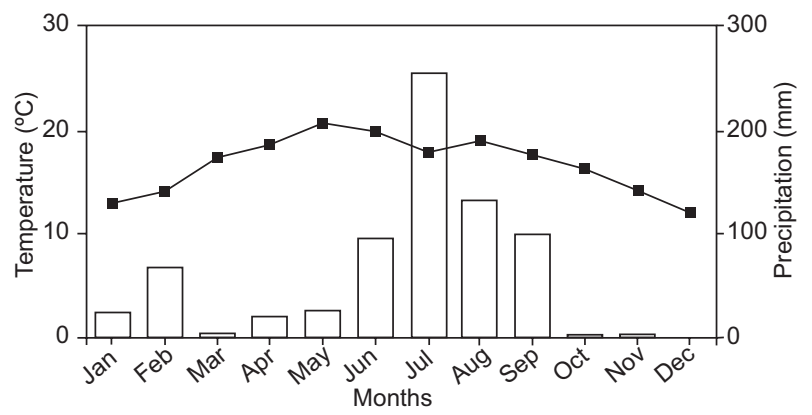

Fig. 1. Temperature and precipitation during 2010.

\subsection{Sampling}

The studies of $\mathrm{CO}_{2}$ exchange were made on three sampling times: T1 (7:30-9:30 LT), T2 (11:30-13:30 LT) and T3 (15:30-17:30 LT). The sampling times were chosen because two of the selected plants have $\mathrm{C} 3$ metabolism and light saturation curves ranged from 500 to $1000 \mu \mathrm{mol} \mathrm{m}^{-2} \mathrm{~s}^{-1}$. The experimental campaign was conducted during 2010, on February 8-12, March 8-12, April 12-16, July 5-9, August 16-20, September 6-10, October 11-15, and November 8-12.

The photosynthetic rate (PR), temperature (T), and relative humidity $(\mathrm{RH})$ were measured with a LI-6400 $\mathrm{CO}_{2}$ analyzer (LI-COR Inc., NE, USA) on leaves of each species exposed to sun. Additionally, the photosynthetic photon flux density (PPFD) was measured with an LI-190SA external sensor (LI-COR Inc., NE, USA). The experimental measurements consisted of three replicates per plant during the three sampling times.

\subsection{Plants}

Measurements were conducted in situ considering three native and abundant REPSA's species. E. gibbiflora is a perennial plant with succulent leaves and stems, belonging to the Loganiaceae family
(Carrillo-Reyes et al., 2009). This plant blooms from November to February, and its leaves have a $24-30 \mathrm{~cm}$ long diameter forming a rosette (Pérez-Calix, 2008). $B$. cordata is an evergreen small tree, belonging to the Loganiaceae family; it blooms from July to October with oblong and pubescent leaves (5-24 cm long, $1.5-10.5 \mathrm{~cm}$ wide). $S$. praecox belongs to the Asteraceae family, and it has a similar lifestyle to B. cordata specie with oblong leaves $2-18 \mathrm{~cm}$ long and 2-10 $\mathrm{cm}$ wide, which reduces its canopy leaf area during the dry season. E. gibbiflora has a Crassulaceae acid metabolism known as CAM which allows the fixation of $\mathrm{CO}_{2}$ at night, while in the light period it assimilates $\mathrm{CO}_{2}$ into chloroplasts by the $\mathrm{C} 3$ cycle (Taiz and Zeigel, 2006). S. praecox and B. cordata have a Calvin-Benson cycle metabolism, allowing the fixation and assimilation of $\mathrm{CO}_{2}$ to form organic compounds, and the photosynthesis takes place in chloroplasts (Nobel, 2009).

\subsection{Population and density}

In order to estimate the number of individuals from each species in the REPSA, eight quadrants of 10 by $10 \mathrm{~m}$ were selected. The sampling method was selective: the numbers of individuals, branches and leaves were counted in each quadrant for the three species in both climatic seasons.

In order to calculate the total $\mathrm{CO}_{2}$ captured and emitted by the REPSA, we averaged the number of individuals for each species in eight quadrants. The results (six, seven and 79 for $B$. cordata, S. praecox, and $E$. gibbiflora, respectively) were then extrapolated to the REPSA. We also used the average leaf area (LA) to calculate the surface and average branches per species, in order to estimate the total contribution of REPSA. Applying a destructive method, samples and branches were taken randomly from each species in all quadrants, and then the leaf area was measured using a LI-3000 (LI-COR Inc., NE, USA).

\section{5 Estimation of $\mathrm{CO}_{2}$ (capture and emission)}

The $\mathrm{CO}_{2}$ exchange between the species and the atmosphere was estimated using average values of the photosynthetic rate, plant population and leaf area of each plant during three schedules in both seasons (dry and rainy). The estimation of $\mathrm{CO}_{2}$ was performed with the following equation:

$\mathrm{CO}_{2}($ estimated $)=(\mathrm{PR} \times \mathrm{t} \times \mathrm{LA}) / \mathrm{RA}$ 
where PR represents the photosynthetic rate $\left(\mathrm{kg} \mathrm{CO}_{2}\right)$, $\mathrm{t}$ the sampling time (s), LA the leaf area $\left(\mathrm{m}^{2}\right)$, and RA the REPSA area $\left(\mathrm{m}^{2}\right)$. Positive values of $\mathrm{CO}_{2}$ indicate capture and negative values represent emissions from the plant to the environment.

\section{6 Statistical analysis}

Correlation coefficient was used to test relations of PR among temperature, PPFD and relative humidity (Statistics R2015a, Matlab). Data are presented as the means of three tests and standard error.

\section{Results and discussion}

3.1 Photosynthetic rate, photosynthetic photon flux density, temperature and relative humidity

The maximum average temperature was $27^{\circ} \mathrm{C}$ in April (dry season), while the minimum was $22{ }^{\circ} \mathrm{C}$ measured in September, at the end of the rainy season. Figure 2 shows the averages of PR, PPFD, T and $\mathrm{RH}$ for the three sampling times. We also analyzed the correlation coefficients between these variables.

The PR changed both in the dry and rainy seasons for all species (Fig. 2a, d, g). B. cordata had a maximum PR of $29 \mu \mathrm{mol} \mathrm{CO} \mathrm{CO}^{-2} \mathrm{~s}^{-1}$ in April and a minimum of $5 \mu \mathrm{mol} \mathrm{CO} \mathrm{m}^{-2} \mathrm{~s}^{-1}$ in October (Fig. 2a); it also showed a good correlation between PR and PPFD.
However, T and RH showed very poor correlations (Table I). S. praecox loses its leaves during the dry season; in April PR reached $27 \mu \mathrm{mol} \mathrm{CO}_{2} \mathrm{~m}^{-2} \mathrm{~s}^{-1}$, in October it decreased to $4 \mu \mathrm{mol} \mathrm{CO} \mathrm{CO}^{-2} \mathrm{~s}^{-1}$, from July to October it ranged from 6.72 to $4.28 \mu \mathrm{mol}$ $\mathrm{CO}_{2} \mathrm{~m}^{-2} \mathrm{~s}^{-1}$, and in April it increased to $27 \mu \mathrm{mol}$ $\mathrm{CO}_{2} \mathrm{~m}^{-2} \mathrm{~s}^{-1}$ showing a strong change from one season to another (Fig. 2d). Temperature range was $21-23^{\circ} \mathrm{C}$ in the rainy season and $28{ }^{\circ} \mathrm{C}$ in the dry season (Fig. 2e), both cases showing a good correlation coefficient among PR, PPFD, and T $(r=0.96$, Table I). E. gibbiflora had a totally different behavior and the correlation coefficients of PR indicated respiration instead of photosynthesis processes. PR increased from -57 to $-21 \mu \mathrm{mol}$ $\mathrm{CO}_{2} \mathrm{~m}^{-2} \mathrm{~s}^{-1}$ from February to April, but in the rainy season it was positive, ranging from 1-5 $\mu \mathrm{mol}$ $\mathrm{CO}_{2} \mathrm{~m}^{-2} \mathrm{~s}^{-1}$. Also, PPFD changed from $600 \mu \mathrm{mol}$ $\mathrm{m}^{-2} \mathrm{~s}^{-1}$ during the dry season to $350 \mu \mathrm{mol} \mathrm{m} \mathrm{m}^{-2} \mathrm{~s}^{-1}$ in the rainy season (Fig. $2 \mathrm{~g}$ ). PR and PPFD had an $r=-0.78$, perhaps indicating an inverse relationship between both variables.

Analysis of normalized difference vegetation indexes (NDVI) was also performed to identify changes of greenery in both measuring seasons, using information of the MODIS from the Earth Observing
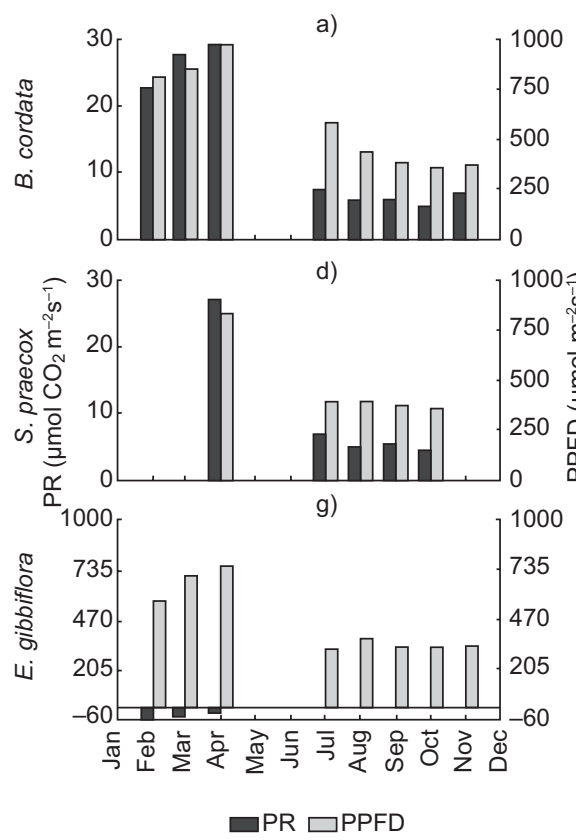

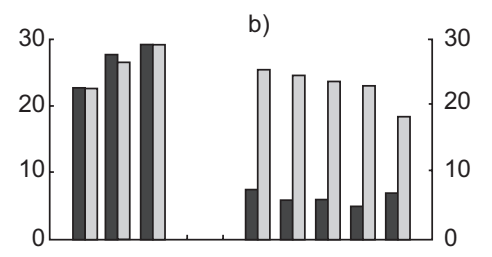

e)

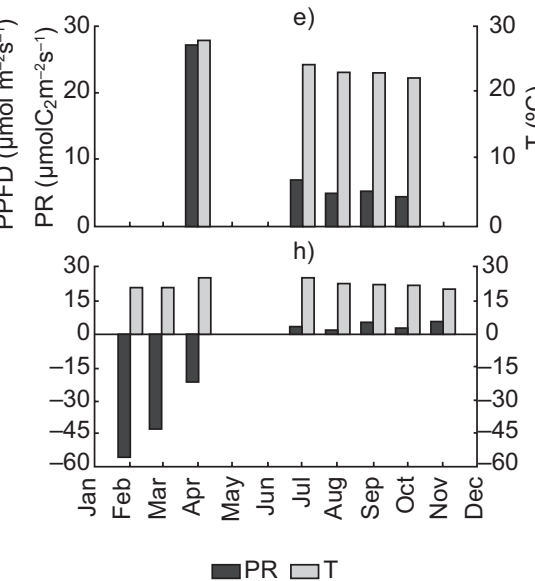

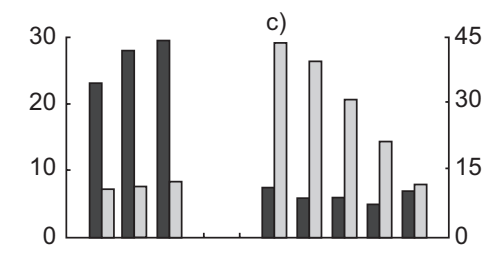
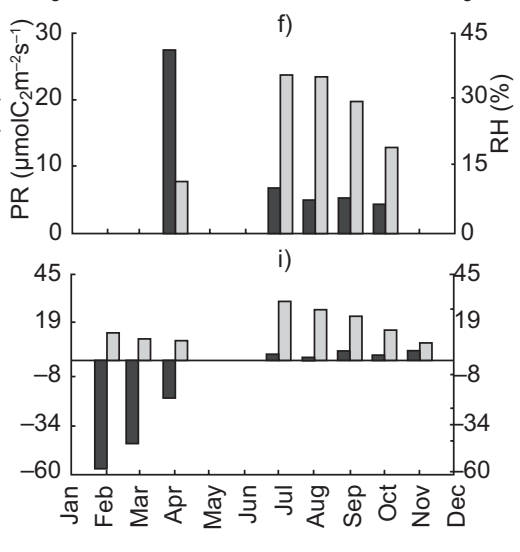

Fig. 2. Photosynthetic rate vs. photosynthetic photon flux density averages (a, d, and g); photosynthetic rate vs. temperature (b, e and h), and photosynthetic rate vs. relative humidity (c, f and i) for B. cordata, S. praecox and E. gibbiflora, respectively. 
Table I. Cross correlation of variables for B. cordata, S. praecox and E. gibbiflora.

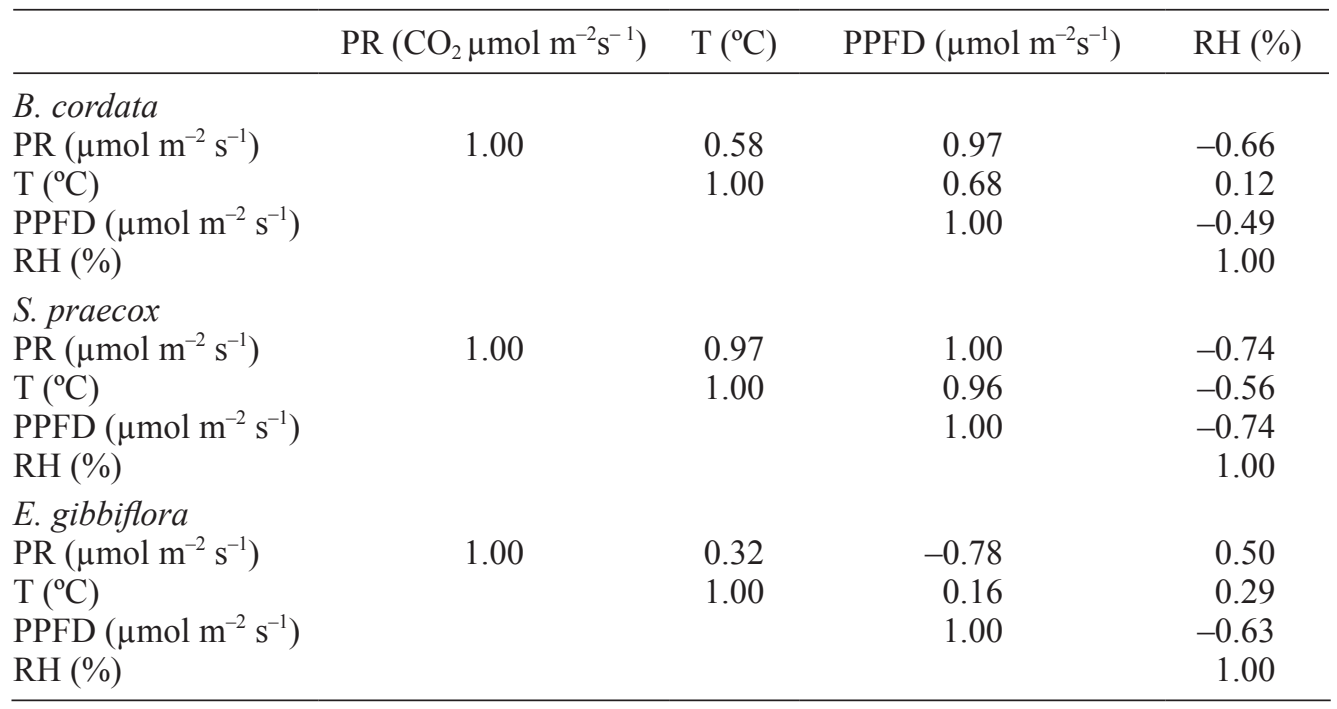

System (EOS). Figure 3 shows the results and changes on greenery along the year. July presented the highest value of the rainy season.

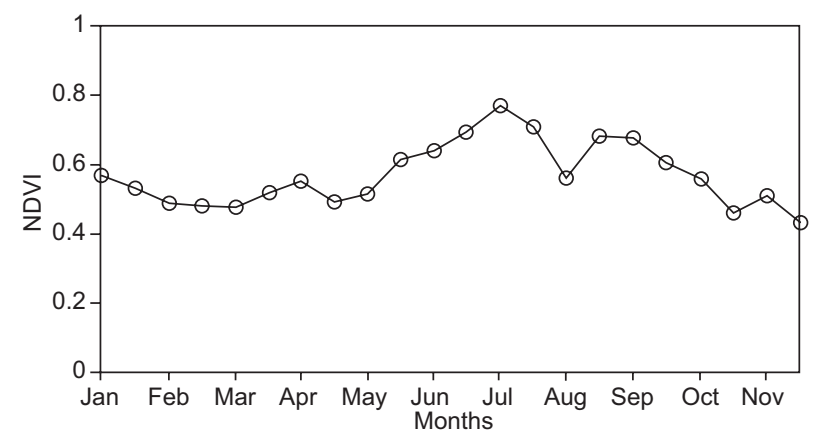

Fig. 3. Annual NDVI changes on greenery in 2010.

\subsection{Estimated $\mathrm{CO}_{2}$ (capture and emission)}

Table II shows the results of $\mathrm{CO}_{2}$ fluxes (capture and emission) estimated in the REPSA. B. cordata and $S$. praecox species had similar behavior in capturing $\mathrm{CO}_{2}$ during both seasons, with 4.03 and $3.25 \mathrm{~kg} \mathrm{CO}_{2}$ in the three sampling times. During the rainy season there was a reduction in the capture of $\mathrm{CO}_{2}$, decreasing to $3.25 \mathrm{~kg}$ for $B$. cordata and $0.63 \mathrm{~kg}$ for $S$. praecox. On the other hand, E. gibbiflora showed negative values in February, March, and April, indicating respiration processes, so the average emitted $\mathrm{CO}_{2}$ was $11.44 \mathrm{~kg}$ in the dry season and the average captured $\mathrm{CO}_{2}$ was $1.12 \mathrm{~kg}$ in the rainy season.
PR and PPFD for B. cordata and S. praecox showed a similar behavior on both the dry and rainy seasons. Those species had higher PR in the dry than in the rainy season. The results show the relevance of solar radiation by increasing the photosynthetic rate for this species (Larcher, 2003; Marur and Faria, 2006).

E. gibbiflora had a totally different behavior, PR showed negative values on the dry season, indicating respiration and therefore $\mathrm{CO}_{2}$ released to the environment. The results are related to the facultative metabolism (Crassulacean acid metabolism) that captures $\mathrm{CO}_{2}$ during the night to prevent the loss of water and also decreases its photosynthetic rate during the day. However, in the rainy season, this species showed photosynthetic activity capturing carbon dioxide probably caused by stomatal opening in short periods of the day (Geydan and Melgarejo, 2005; Andrade et al., 2007).

Temperature has a direct influence on the activities of plants; it promotes physiological activities, increasing the photosynthetic rate (Lambers et al., 2008), but high temperatures cause stomata closure reducing gas exchange. The environmental temperature average throughout the measuring campaign was $25^{\circ} \mathrm{C}$, thus favoring the photosynthetic activity of $B$. cordata and $S$. praecox in this microenvironment.

Photosynthesis cycles are influenced by seasonal changes, which increase in the first months of the year and decrease during fall, with the loss of leaves (Lambers et al., 2008). However, environmental variables such as temperature, PPFD and 
Table II. Estimation of $\mathrm{CO}_{2}$ fluxes by B. cordata, S. praecox and E. gibbiflora in both seasons.

\begin{tabular}{|c|c|c|c|c|c|}
\hline & \multicolumn{2}{|c|}{ Dry season } & & \multicolumn{2}{|c|}{ Rainy season } \\
\hline & $\mathrm{PR}\left(\mu \mathrm{mol} \mathrm{CO} \mathrm{CO}^{-2} \mathrm{~s}^{-1}\right)$ & Total $\mathrm{CO}_{2}(\mathrm{~kg})$ & & $\mathrm{PR}\left(\mu \mathrm{mol} \mathrm{CO} \mathrm{CO}^{-2} \mathrm{~s}^{-1}\right)$ & Total $\mathrm{CO}_{2}(\mathrm{~kg})$ \\
\hline \multicolumn{6}{|c|}{ B. cordata } \\
\hline Feb & 22.69 & 4.35 & Jul & 7.36 & 1.41 \\
\hline Mar & 27.71 & 5.31 & Aug & 5.85 & 1.12 \\
\hline Apr & 29.25 & 5.61 & Sep & 5.85 & 1.12 \\
\hline Nov & 6.87 & 0.87 & Oct & 4.93 & 0.95 \\
\hline \multicolumn{6}{|c|}{ S. praecox } \\
\hline Feb & & & Jul & 6.72 & 0.81 \\
\hline Mar & & & Aug & 4.75 & 0.57 \\
\hline Apr & 26.97 & 3.25 & Sep & 5.25 & 0.63 \\
\hline Nov & & & Oct & 4.28 & 0.52 \\
\hline \multicolumn{6}{|c|}{ E. gibbiflora } \\
\hline Feb & -57.05 & -22.44 & Jul & 3.21 & 1.26 \\
\hline Mar & -43.72 & -17.19 & Aug & 1.17 & 0.46 \\
\hline Apr & -21.16 & -8.32 & Sep & 5.25 & 2.06 \\
\hline Nov & 5.57 & 2.19 & Oct & 2.85 & 1.12 \\
\hline
\end{tabular}

RH are determinant for photosynthesis responses. According to the results, the $\mathrm{RH}$ average was $11 \%$ during the dry season, suggesting that low RH values are appropriate for $\mathrm{CO}_{2}$ capture by $B$. cordata and $S$. praecox. Average $\mathrm{RH}$ during rainy season increased to $40 \%$, reducing plant transpiration and preventing water loss. Some studies show that in forests, clouds dipping favors photosynthesis (Letts and Mulligan, 2005; Johnson and Smith, 2008), but in these species sunny days are essential. NDVI showed that in the reserve, greenness intensity is greater than 0.4 ; this value is an indicator that suggests photosynthesis and secures primary productivity in this place.

The results showed a decrease of PR and PPFD during the rainy season for the species $B$. cordata and $S$. praecox. It has been suggested that clouds present in this season affect the processes of photosynthesis. It was also observed that the microenvironment and physiological variables of these species are critical in their response to photosynthesis. The contribution of the reserve according to the estimates, allows knowing the $\mathrm{CO}_{2}$ balance of these two species during the dry and rainy seasons, which was 3.86 and $3.03 \mathrm{~kg}$ $\mathrm{CO}_{2}$, respectively.

\section{Conclusions}

Results are a first approximation to $\mathrm{CO}_{2}$ exchange in an urban ecosystem. This information could be integrated into ecosystem models to update and validate data. B. cordata and S. praecox have a similar behavior in $\mathrm{CO}_{2}$ exchange, but E. gibbiflora shows a totally different behavior that could overestimate the $\mathrm{CO}_{2}$ capture in the REPSA. For a better understanding of $\mathrm{CO}_{2}$ exchange in this reserve, we recommend that night measurements should be performed too.

\section{Acknowledgments}

We thank M. I. Saavedra for her technical assistance; also H. Padilla, J. García, E. Montes, A. Ysunza, J. Rosas, R. López, E. Galindo, and T. Castillo for their help during the measuring campaign.

\section{References}

Andrade J. L., E. de la Barrera, C. Reyes-García C, M. F, Ricalde M.F, G.Vargas-Soto and J. C. Cervera, 2007. El metabolismo ácido de las crasuláceas: diversidad, fisiología ambiental y productividad. Bol. Soc. Bot. Méx. 81, 37-50.

Carrillo-Reyes P., V. Sosa and M. E. Mort, 2009. Molecular phylogeny of the Acre clade (Crassulaceae): Dealing with the lack of definitions for Echeveria and Sedum. Mol. Phylogenet. Evol. 53, 267-276, doi: 10.1016/j. ympev.2009.05.022.

Castillo-Argüero S., Y. Martínez Orea, M. A. Romero Romero, P. Guadarrama Chávez, O. Núñez Castillo, I. Sánchez Guillén and J. A Meave, 2007. La Reserva Ecológica del Pedregal de San Ángel, aspectos florísticos y ecológicos. Secretaría Ejecutiva de la Reserva Ecológica del Pedregal de San Ángel de Ciudad Universitaria, México, 11-15. 
Chávez C. and G. Ceballos, 2009. Implications for conservation of the species diversity and population dynamics of small mammals in an isolated reserve in Mexico City. Nat. Area. J. 29, 27-41, doi: http://dx.doi. org/10.3375/043.029.0104.

FAO, 2010. Evaluación de los recursos forestales mundiales 2010. Organización de las Naciones Unidas para la Agricultura y la Alimentación, Roma, 11-45, ISBN 97892-5-306654-4.

Geydan T. D. and L. M. Melgarejo, 2005. Metabolismo ácido de las crasuláceas. Acta Biológica Colombiana 10, 3-15.

Harnos N., Z. Nagy, J. Balogh, Z. Tuba, 2006. Modeling net photosynthetic rate of temperate dry grassland species and winter wheat at elevated air $\mathrm{CO}_{2}$ concentration. Appl. Ecol. Env. Res. 4, 47-53.IPCC, 2007. Summary for policymakers. In: Climate change 2007: The physical science basis. Contribution of Working Group I to the Fourth Assessment Report of the Intergovernmental Panel on Climate Change (S. Solomon, D. Qin, M. Manning, Z. Chen, M. Marquis, K. B. Averyt, M. Tignor and H. L. Miller, Eds.). Cambridge University Press, Cambridge, United Kingdom and New York, 1-18.

INE, 2010. Inventario Nacional de Emisiones de Gases Efecto Invernadero (IV). Instituto Nacional de Ecología y Cambio Climático, México, 384 pp.

Jáuregui O. E., 2000. El clima de la Ciudad de México, Instituto de Geografía, Universidad Nacional Autónoma de México, México, 139 pp.

Johnson D. M. and W. K. Smith, 2008. Cloud immersion alters microclimate, photosynthesis and water relations in Rhododendrom catawbiense and Abies fraseri seedlings in the southern Appalachian Mountains, USA. $J$. Exp. Bot. 47, 639-645.

Kim S. H. and J. H. Lieth, 2003. A coupled model of photosynthesis, stomatal conductance and transpiration for a rose leaf (Rosa hybrida L). Ann. Bot. 91, 771-781, doi:10.1093/aob/mcg080.

Kitao M., T. T. Lei, T. Koike, M. Kayama, H. Tobita and Y. Maruyama, 2007. Interaction of drought and elevated $\mathrm{CO}_{2}$ concentration on photosynthetic down regulation and susceptibility to photo inhibition in Japanese white birch seedlings grown with limited $\mathrm{N}$ availability. Tree Physiol. 27, 727-735.

Kordowski K. and W. Kuttler, 2010. Carbon dioxide fluxes over an urban park area. Atmos. Environ. 44, 27222730, doi:10.1016/j.atmosenv.2010.04.039.

Lambers H., F. S Chapin and T. L. Pons, 2008. Plant physiological ecology. Springer, New York, 605 pp.
Larcher W., 2003. Physiological plant ecology. Ecophysiology and stress physiology of functional groups. Springer, Berlin, 514 pp.

Letts M. G. and M. Mulligan, 2005. The impact of light quality and leaf wetness on photosynthesis in the northwest Andean tropical, montane cloud forest. J. Trop. Ecol. 21, 549-557, doi:10.1017/S0266467405002488.

Long S. P. and C. J. Bernacchi, 2003. Gas exchange measurements, what can they tell us about the underlying limitations to photosynthesis? Procedures and sources of error. J. Exp. Bot. 54, 2393-2401, doi:0.1093/jxb/ erg262.

Marur C. J. and R. T. Faria, 2006. Photosynthesis of individual leaves in a coffee plant. Acta Sci.-Agron. 28, 331-335.

Myers D. A., R. B Thomas and E. H. de Lucia, 1999. Photosynthetic responses of loblolly pine (Pinus taeda) needles to experimental reduction in sink demand. Tree Physiol. 19, 235-242.

NOAA 2014. Annual Data Atmospheric $\mathrm{CO}_{2}$ Concentration. Mauna Loa $\mathrm{CO}_{2}$ Data IOP Publishing: PhysicsWeb. Available at: https://www.climate.gov/ news-features/understanding-climate/2014-state-climate-carbon-dioxide.

Nobel Park S., 2009. Physicochemical and environmental plant physiology. Academic Press, California, 567 pp.

Okimoto Y., A. Nose, Y. Katsuta, Y. Tateda, S. Agarie and K. Ikeda, 2007. Gas exchange analysis for estimating net $\mathrm{CO}_{2}$ fixation capacity of mangrove (Rhizophora stylosa) forest in the mouth of river Fukido, Ishigaki Island, Japan. Plant Prod. Sci. 10, 303-313, doi:10.1626/ pps.10.303.

Pérez-Calix E., 2008. Crassulaceae. Flora del Bajío y de Regiones Adyacentes 156, 1-141.

Rzedowski J., 1954. Vegetación del Pedregal de San Ángel (Distrito Federal, México). Anales de la Escuela Nacional Ciencias Biológicas 8, 59-129.

Sharkey T. D., C. J. Bernacchi, G. D. Farquhar and E. L. Singsaas, 2007. Fitting photosynthetic carbon dioxide response curves for C3 leaves. Plant Cell Environ 30, 1035-1040, doi:10.1111/j.1365-3040.2007.01710.x.

Schultz R. H., 2003. Extension of a Farquhar model for limitations of leaf photosynthesis induced by light environment, phenology and leaf age in grapevines (Vitis vinifera L. cvv. White Riesling and Zinfandel). Functional Plant Biology 30, 673-687, doi:10.1071/ FP02146.

Taiz L. and E. Zeigel, 2006. Plant physiology. Sinauer Associates, Sunderland, $623 \mathrm{pp}$. 
Velasco E., M. Roth., S. H. Tan, M. Quak, S. D. A. Nabarro and L. Norford, 2013. The role of vegetation in the $\mathrm{CO}_{2}$ flux from a tropical urban neighborhood. Atmos. Chem. Phys. 13, 7267-7310, doi:10.5194/acp-13-10185-2013.

$\mathrm{Xu}$ L. and D. D. Baldocchi, 2003. Seasonal trends in photosynthetic parameters and stomatal conductance of blue oak (Quercus donglasii) under prolonged summer drought and high temperature. Tree Physiol. $23,865-877$.
Yang J., J. McBride, J. Zhou and Z. Sun, 2005. The urban forest in Beijing and its role in air pollution reduction. Urban For. Urban Gree. 3, 65-78, doi: doi:10.1016/j. ufug.2004.09.001.

Zhao M., F. A. Heinsch, R. R. Nemani and S. W. Running, 2005. Improvements of the MODIS terrestrial gross and net primary production global data set. Remote Sens. Environ. 95, 164-176, doi:10.1016/j. rse.2004.12.011. 